\title{
ANTIBACTERIAL EFFECTS OF SOME ANTISEPTICS AND DISINFECTANTS
}

\author{
A. K. Saha*, M. F. Haque, S. Karmaker and M. K. Mohanta \\ Genetics and Molecular Biology Laboratory, Department of Zoology, University of Rajshahi, Rajshahi 6205, \\ Bangladesh
}

\begin{abstract}
Antimicrobial effects of six antiseptics and disinfectants were studied against five pathogenic bacteria. Different pathogens responded differently to different antiseptics and disinfectants. Antibacterial effects of the antiseptics and disinfectants were also concentration dependent. Formalin and hydrogen peroxide were highly effective against all the pathogens used while phenyl and iodine were least effective. Dettol and Savlon showed moderate antibacterial effects.
\end{abstract}

Key word: Antiseptics, disinfectants, pathogen, sensitivity.

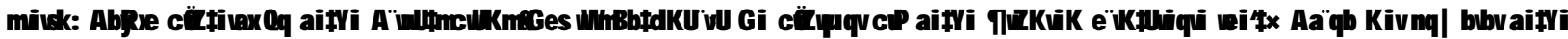

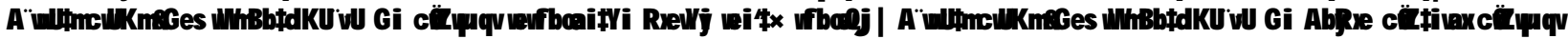

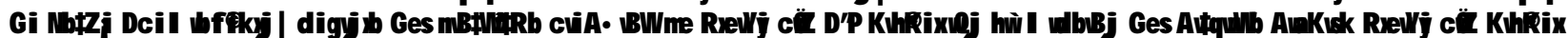

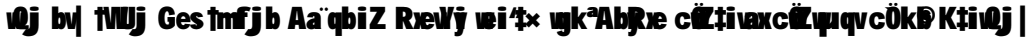

\section{Introduction}

Antiseptics and disinfectants are used extensively in hospitals and other health care centres to control the growth of microbes on both living tissues and inanimate objects. They are essential parts of infection control practices and aid in the prevention of nosocomial infections (Larson et al. 1991). But a common problem is the selection of disinfectants and antiseptics because different pathogens vary in their response to different antiseptics or disinfectants (Russell 1996).

Dettol is widely used in homes and healthcare settings for various purposes including disinfection of skin, objects and equipments, as well as environmental surfaces. With prior cleaning before application, the number of microorganisms colonizing the skin and surfaces are greatly reduced (Rutala 1996). The antimicrobial properties of chloroxylenol, the main chemical constituent of Dettol and other chlorinated phenols have been extensively studied (Hugo and Bloomfield 1971a). The antimicrobial properties of the disinfectant against some pathogenic bacteria have earlier been reported (Mellefont et al. 2003). Moreover, microorganisms are continuously acquiring resistance to new antiseptics and disinfectants, as a result, no single antiseptic or disinfectant will be appropriate for all pathogens (Tortora et al. 1998). Therefore, it is necessary to evaluate the effectiveness of an antiseptic or disinfectant against a specific pathogen so that an appropriate agent can be easily selected. In this paper, antibacterial activity of six groups of antiseptics and disinfectants against five pathogens using filter paper disc diffusion method are discussed.

*Corresponding author: anadroma@yahoo.com

\section{Materials and Methods}

Six types of antiseptics and disinfectants, namely Dettol (Chloroxylenol), Savlon (Chlorhexidine Gluconate and Cetrimide), Iodine, Phenyl, Formalin and Hydrogen peroxide $\left(\mathrm{H}_{2} \mathrm{O}_{2}\right)$; and five pathogenic bacteria, viz. Staphylococcus aureus, Salmonella typhi, Shigella dysenteriae, Klebsiella species and Escherichia coli were used in this experiment. For each test, 100ml Luria Bartini broth was inoculated with few cells of a pathogenic bacterium and incubated at $37^{\circ} \mathrm{C}$ for 24 hours in rotary sacker rotate at $120 \mathrm{rpm}$. After incubation, $1 \mathrm{ml}$ of broth culture was spread uniformly on a nutrient agar plate with a sterile glass spreader. The plate was air-dried for few minutes. Sterile filter paper discs were soaked with 100\%, 50\%, 25\%, $10 \%$ and 5\% concentration of commercial form of different antiseptics and disinfectants. Then these discs were placed on inoculated nutrient agar plates which were incubated at $37^{\circ} \mathrm{C}$ for 24 hours. After incubation, clear zones indicated inhibition of growth of the microorganisms. The zones around the discs were measured and recorded.

\section{Results and Discussion}

The results show that different types of microorganisms vary in their response to different types of antiseptics and disinfectants. Phenyl was the least effective against all the pathogens under study because the zone of inhibition ranged from $6 \mathrm{~mm}$ to $11 \mathrm{~mm}$. None of the five pathogens was sensitive to phenyl. On the other hand, formalin was found highly effective against all pathogens where the zones of inhibition ranged from 20 $\mathrm{mm}$ to $51 \mathrm{~mm}$ (Fig.1). Hydrogen peroxide was also 
highly effective to all the pathogens. All the five pathogens were sensitive to formalin and hydrogen peroxide at different concentrations. Antibacterial effect of Dettol was better against $S$. aureus, $S$. typhi and $E$. coli than against $S$. dysenteriae and $K$. sp. Similarly, Savlon was more effective against $S$. aureus, S. typhi and $S$. dysenteriae than against $E$. coli. Iodine showed better antibacterial efficacy against $S$. aureus and $E$. coli than against the remaining pathogens. Of these three pathogens, only $S$. dysenteriae was sensitive to a saturated solution of iodine.

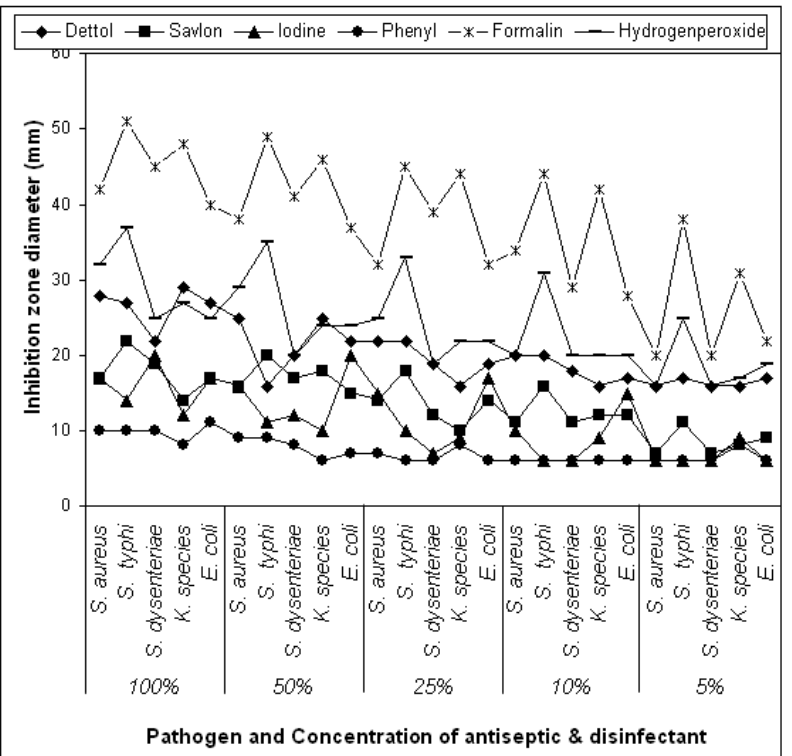

Fig. 1. Antibacterial effects of some antiseptics and disinfectants.

Resistance to antibacterial agents can be either a natural property of an organism or acquired by mutation or acquisition of plasmids or transposons. Intrinsic resistance is demonstrated by Gram-negative bacteria, bacterial spores, mycobacteria, and under certain conditions, Staphylococci. Acquired, plasmid-mediated resistance is most widely associated with mercury compounds and other metallic salts (Chopra 1991).

Antibiotic resistance by various mechanisms has increased worldwide in bacterial pathogens leading to treatment failures in human and animal infectious diseases (WHO 2007). Resistance against antibiotics by pathogenic bacteria is a major concern in the antimicrobial therapy for both humans and animals. Bacteria are able to adapt rapidly to new environmental conditions such as the presence of antimicrobial molecules, and as a consequence, resistance increases with the antimicrobial use (Falagas and Bliziotis 2007; Jansen et al. 2006). Serious concerns about bacterial drug resistance from nosocomial, community-acquired and food-borne pathogens have been growing for a number of years and have been raised at both national and international levels (Jansen et al. 2006; WHO 2007).

Results of this experiment indicate that different pathogens acquired resistance to different antiseptics and disinfectants. The results also suggest that the antibacterial effects of antiseptics and disinfectants are not only dependent on the types of antiseptics and disinfectant but also on their concentrations. Similar results were found by Shaker et al. (1986). They demonstrated that many biocides are bactericidal or bacteristatic at low concentrations for nonsporulating bacteria, but high concentrations may be necessary to achieve a sporicidal effect. By contrast, even at high concentrations alcohol, phenolics and chlorhexidine showed lack a sporicidal effect.

In the present experiment formalin was highly effective against all the pathogens. This is in agreement with Milhaud (1973), who reported that development of resistance during sporulation to formaldehyde was an early event but depended to some extent on the concentration of formaldehyde used. Our results also show that all studied pathogens are sensitive to $5 \%$ hydrogen peroxide. Similarly, Tortora et al. (1998) reported that $3 \%$ solution of hydrogen peroxide can be used as an antiseptic. When hydrogen peroxide comes into contact with the catalase enzyme in cells it is broken down into water and oxygen. S. aureus is a Gram-positive bacterium and the remaining four are Gram-negative bacteria. Russell (1996) reported that Gram-negative bacteria are generally more resistant to antiseptics and disinfectants than are the nonsporulating, non-mycobacterial Gram-positive bacteria. But results of this experiment showed no remarkable difference in resistance between Gram-positive and Gram-negative bacteria. Here, S. aureus may have acquired resistance to some antiseptics and disinfectants as mentioned by Russell (1997). It has been known for several years that some antiseptics and disinfectants are somewhat less inhibitory to $S$. aureus strains that contain a plasmid carrying genes encoding resistance to the aminoglycoside antibiotic gentamicin (Al-Masaudi 1991; Sasatsu 1995). According to Mycock (1985), MRSA strains showed a remarkable increase in tolerance (at least 5,000-fold) to iodine. A similar result is found in present experiment. As formalin is corrosive for human beings, it is better to use hydrogen peroxide for antiseptic purposes.

\section{Conclusion}

From the above results it can be concluded that formalin is corrosive for human being, therefore, it is better to use hydrogen peroxide as antiseptic. 


\section{Reference}

Al-Masaudi SB, Day MJ, Russell AD. 1991. Antimicrobial resistance and gene transfer in Staphylococcus aureus. J Appl Bacteriol 70, 279-290.

Chopra I. 1991. Bacterial resistance to disinfectants, antiseptics and toxic metal ions. Soc Appl Bacteriol Tech Ser 27,45-64.

Falagas ME and Bliziotis IA. 2007. Pandrug-resistant Gramnegative bacteria: the dawn of the post-antibiotic era. Int J Antimicrob Agents 29, 630-6.

Hugo WA, Bloomfield SF.1971a. Studies on the mode of action of phenolic antibacterial agent fenticlor against Staphylococcus aureus and Escherichia coli 1. Adsorption of fenticlor by the bacterial cell and its antibacterial activity. J Appl Bacteriol. 34(3), 557-567.

Jansen WT, Van der Bruggen JT, Verhoef $\mathrm{J}$ and Fluit AC. 2006. Bacterial resistance: a sensitive issue complexity of the challenge and containment strategy in Europe. Drug Resist Updat. 9,123-33.

Larson EL and Morton HE. 1991. Alcohols. In: Philadelphia, Pa: Lea Febiger; p. 191-203.

Milhaud P. and Balassa G. 1973. Biochemical genetics of bacterial sporulation. IV. Sequential development of resistance to chemical and physical agents during sporulation of Bacillus subtilis. Mol Gen Genet 125, 241-250.
Mycock G. 1985. Methicillin/antiseptic-resistant Staphylococcus aureus. Lancet 2, 949-950.

Mellefont LA, McMeekin TA, Ross T. 2003. The effect of abrupt osmotic shifts on the lag phase duration of food borne bacteria. Int. J Food Microbiol. 83, 281-293.

Russell AD. 1996. Activity of biocides against mycobacteria. J Appl Bacteriol, Symp Suppl 81, 87-101.

Russell AD. 1997. Plasmids and bacterial resistance to biocides. J Appl Microbiol 82, 155-165.

Rutala WA.1996. APIC guideline for selection and use of disinfectants. Am. J Infect Contr. 24, 313-342.

Sasatsu M, Shirai Y, Hase M, Noguchi N, Kono M, Behr H, Freney J, and Arai T. 1995. The origin of the antisepticresistance gene ebr in Staphylococcus aureus. Microbios 84, 161-169.

Shaker LA, Russell AD, and Furr JR. 1986. Aspects of the action of chlorhexidine on bacterial spores. Int $\mathrm{J}$ Pharm 34, 51-56.

Tortora GJ, Berdell R Funke and Christine L Case. 1998. Chemical methods of microbial control. In: Microbiology, pp. 191. Benjamin Cumming Publishing Company, California, USA.

WHO 2007. A safer future: Global public health security in the $21^{\text {st }}$ century (accessed 25 February 2009). 